\title{
Assessment of Promoter hypermethylation of APC and BRCA1 in endometrial cancer.
}

\author{
Shivanandappa N. ${ }^{1}$, N Swamy S. $^{2}$, Kumar S S. ${ }^{3}$, Sheshadri S. ${ }^{4}$, Venkateshaiah Reddihalli P. ${ }^{5}$, \\ Gawari R. ${ }^{\text {** }}$ \\ DOI: https://doi.org/10.17511/ijmrr.2021.i04.06 \\ 1 Nagaratna Shivanandappa, Research Scholar, Department of Biochemistry, Kidwai Memorial Institute of Oncology, Bangalore, Karnataka, \\ India. \\ 2 Shalini N Swamy, Research Scholar, Department of Biochemistry, Kidwai Memorial Institute of Oncology, Bangalore, Karnataka, India. \\ 3 Sandeep Kumar S, Senior Research Fellow, Department of Biochemistry, Kidwai Memorial Institute of Oncology, Bangalore, Karnataka, \\ India. \\ 4 Suma Sheshadri, Associate Professor, Department of Pathology, Kidwai Memorial Institute of Oncology, Bangalore, Karnataka, India. \\ 5 Pallavi Venkateshaiah Reddihalli, Professor, Department of Gynaecology, Kidwai Memorial Institute of Oncology, Bangalore, Karnataka, \\ India. \\ 6* Ramesh Gawari, Professor, Department of Biochemistry, Kidwai Memorial Institute of Oncology, Bangalore, Karnataka, India.
}

Introduction: Endometrial cancer is one of the most common cancers in women worldwide. The underlying cause of endometrial tumorigenesis remains elusive. Several genetic and epigenetic alterations are known to be involved in the carcinogenesis of endometrial carcinoma. One important and early epigenetic alteration that is attributed to endometrial carcinoma is the aberrant promoter hypermethylation of gene promoters. In this study, we have assessed the aberrant promoter hypermethylation of APC and BRCA1 in 78 endometrial cancer samples. Methods: Histologically confirmed tumour tissue samples were obtained post-surgery and DNA was extracted. The DNA was subjected to sodium bisulfite conversion and used as a template for a polymerase chain reaction. The PCR was performed using a nested PCR followed by methylation specific PCR. Results: A $33.33 \%$ and $46.15 \%$ methylation frequency was observed for APC and BRCA1 genes respectively. A higher percentage of methylation was observed in stage IV for APC $(66.66 \%)$ and in stage II for BRCA1 $(88.88 \%)$. Conclusion: Aberrant promoter hypermethylation is an early event in endometrial carcinoma and can serve as a useful molecular marker for diagnosis and prognosis of the disease along with existing screening modalities.

Keywords: Hypermethylation, Endometrial cancer, APC, BRCA1

\section{Corresponding Author}

Ramesh Gawari, Professor, Department of Biochemistry, Kidwai Memorial Institute of Oncology, Bangalore, Karnataka, India. Email: gdrramesh@gmail.com

\section{How to Cite this Article}

Shivanandappa N, Swamy SN, Kumar SS, Sheshadri S, Reddihalli PV, Gawari R. Assessment of Promoter hypermethylation of APC and BRCA1 in endometrial cancer.. Int J Med Res Rev. 2021;9(4):241-248. Available From

https://ijmrr.medresearch.in/index.php/ijmrr/article/ view/1306
To Browse

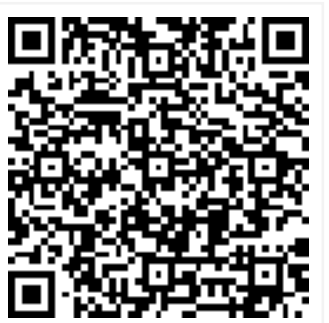

Manuscript Received 2021-05-25

Conflict of Interest No
Review Round 1 2021-06-05

Funding
Review Round 2 2021-06-15

Ethical Approval Yes
Review Round 3 2021-06-25

Plagiarism X-checker $7 \%$
Accepted 2021-07-29

Note

(C) 2021 by Nagaratna Shivanandappa, Shalini N Swamy, Sandeep Kumar S, Suma Sheshadri, Pallavi Venkateshaiah Reddihalli, Ramesh Gawari and Published by Siddharth Health Research and Social Welfare Society. This is an Open Access article licensed under a Creative Commons Attribution 4.0 International License https://creativecommons.org/licenses/by/4.0/ unported [CC BY

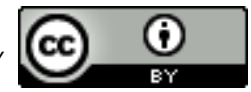




\section{Introduction}

Endometrial cancer is the seventh most common cancer in women worldwide and is one of the most commonly diagnosed cancers in the developed countries. It accounts for about $7 \%$ of new cases and $4 \%$ of cancer-related deaths in women [1-3]. Though the underlying mechanism of tumorigenesis in the endometrium is not fully understood several data suggest the role of various genetic and epigenetic alterations in the process of endometrial carcinogenesis.

The role of epigenetic alterations has gained considerable attention in the past decade. Epigenetic alteration can be defined as a heritable change in gene expression patterns that result without causing any alteration to the nucleotide sequence. One of the most well studied epigenetic alterations is aberrant promoter hypermethylation. During the process of tumor initiation and progression various tumor suppressor genes (TSG) are known to be transcriptionally silenced by the addition of a methyl group to the cytosine residues that reside in the CpG islands of the promoter region. This addition of methyl group to the cytosine prevents the interaction of transcription machinery with the promoter and thereby renders the gene silent (turned off) [4-6].

Adenomatous polyposis coli (APC), is a homodimeric protein of $310 \mathrm{kDa}$ that is expressed in most of the normal epithelial cells [7]. The protein localization of APC is observed in the cytoplasm and nucleus and is known to play a role in the maintenance of cell adhesion, cytoskeletal integrity, cell cycle regulation and wnt pathway [8-13]. The APC protein is known to mediate the cell cycle progression from $\mathrm{G} 1$ to $\mathrm{S}$ phase by its interaction with DLG, a tumour suppressor protein [14]. It maintains the cytoskeletal integrity by regulating microtubule dynamics during cell division [15]. Another major role of APC is to negatively regulate $\beta$-catenin signaling with the aid of GSK-3 $\beta$ and ubiquitin pathway. The inactivation $f$ APC either by genetic or epigenetic alterations lead to the accumulation of $\beta$ catenin activating the wnt pathway [16]. The $\beta$ catenin /TCF-Lef complex is known to regulate the protooncogenes, c-myc, c-jun and cyclin D1 [1722].

Table 1: Primer sequences for Nested and methylation specific PCR:

\begin{tabular}{|l|l|l|c|}
\hline \multicolumn{1}{|c|}{ Gene } & \multicolumn{1}{|c|}{ Forward $\left(5^{\prime}\right.$ to $\left.\mathbf{3}^{\prime}\right)$} & \multicolumn{1}{|c|}{ Reverse $\left(5^{\prime}\right.$ to $\left.\mathbf{3}^{\prime}\right)$} & Amplicon size \\
\hline APC Nested & TGGGYGGGGTTTGTGTTTATT & TACRCCCACACCCAACCAATC & $136 \mathrm{bp}$ \\
\hline
\end{tabular}

Breast cancer susceptibility gene 1 (BRCA1) was mapped to $17 \mathrm{q} 21$ and is a well-established tumor suppressor gene.

BRCA1 gene has 24 exons encoding 1863 amino acid residues [23-25]. The protein is localized within the nucleus of many cell types and is involved in the maintenance of various cellular signaling cascades that are involved in DNA repair, chromatin remodeling, apoptosis and activation of DNA damage checkpoints in the cell cycle. They play a crucial role in the maintenance of genome stability [26-29]. BRCA1 functions majorly via the homologous recombination repair by forming an association with the Mre11/Rad50/NBS1 (MRN) complex [30]. Aberrations in the BCRA1 levels have been attributed to many cancer types and its role has been implicated in the initiation and progression of sporadic breast and ovarian cancers. The BRCA1 gene has been known to be silenced by promoter hypermethylation events in breast and ovarian cancers [31-36]. There have not been studies that have reported the methylation of the BRCA1 gene promoter in endometrial cancer. The current study aims to identify the aberrant promoter hypermethylation frequency of APC and BRCA1 genes in endometrial cancer.

\section{Materials and Methods}

Sample collection: Endometrial carcinoma tissues were obtained from 78 patients diagnosed with endometrial cancer post-surgery.

Inclusion criteria: All primary, chemo naïve endometrial cancers were included in the study.

DNA isolation and bisulfite modification: DNA was isolated from histologically confirmed endometrial carcinoma samples using a DNAeasy mini kit (Qiagen, USA). The DNA was quantified using a spectrophotometer. The DNA was further subjected to sodium bisulfite modification using the EZ DNA methyl lightening kit following the manufacturer's protocol. The modified DNA was used as a template for the methylation specific PCR.

Methylation specific PCR: The assessment of methylation was performed using two steps- nested PCR and Methylation specific PCR (MSP). The primer sequences, reaction conditions for nested and MSP are listed in tables-1-3. 


\begin{tabular}{|l|l|l|}
\hline APC MSP & TATTGCGGAGTGCGGGTC & TCGACGAACTCCCGACGA \\
\hline APC USP & GTGTTTTATTGTGAGTGTGGGTT & CCAATCAACAAACTCCCAACAA \\
\hline BRCA1 Nested & GAGAGGTTGTTGTTAGYGGTAGTTT & TCTAAAAAACCCCACAACCTAGTTT \\
\hline BRCA1 MSP & GGGTTTGCGAGAGCGCGT & AAAACTCAACGAACTCACGCCG \\
\hline BRCA1 USP & TTGGTTTTGTGGTAATGGAAAAGTGT & CAAAAAATCTCAACAAACTCACACCA \\
\hline
\end{tabular}

Table 2: Nested PCR Condition:

\begin{tabular}{|c|c|c|c|c|c|}
\hline \multirow[t]{2}{*}{ Gene } & \multirow[t]{2}{*}{ Initial denaturation $\left({ }^{\circ} \mathrm{C}\right)$} & \multicolumn{3}{|c|}{ Cycling stage X35 } & \multirow[t]{2}{*}{ Final Extension $\left({ }^{\circ} \mathrm{C}\right)$} \\
\hline & & Denaturation $\left({ }^{\circ} \mathrm{C}\right)$ & Annealing $\left({ }^{\circ} \mathrm{C}\right)$ & Extension $\left({ }^{\circ} \mathrm{C}\right)$ & \\
\hline \multirow[t]{2}{*}{ APC } & 95 & 95 & 53 & 72 & 72 \\
\hline & $7 \mathrm{mins}$ & $30 \mathrm{sec}$ & $30 \mathrm{sec}$ & $30 \mathrm{sec}$ & 7 mins \\
\hline \multirow[t]{2}{*}{ BRCA1 } & 95 & 95 & 72 & 72 & 72 \\
\hline & 5 mins & $30 \mathrm{sec}$ & $30 \mathrm{sec}$ & $30 \mathrm{sec}$ & 5 mins \\
\hline
\end{tabular}

Table 3: MSP/USP PCR Condition:

\begin{tabular}{|c|c|c|c|c|c|}
\hline \multirow[t]{2}{*}{ Gene } & \multirow[t]{2}{*}{ Initial denaturation $\left({ }^{\circ} \mathrm{C}\right)$} & \multicolumn{3}{|c|}{ Cycling stage X35 } & \multirow[t]{2}{*}{ Final extension $\left({ }^{\circ} \mathbf{C}\right)$} \\
\hline & & Denaturation $\left({ }^{\circ} \mathrm{C}\right)$ & Annealing $\left({ }^{\circ} \mathrm{C}\right)$ & Extension $\left({ }^{\circ} \mathrm{C}\right)$ & \\
\hline \multirow[t]{2}{*}{ APC } & 95 & 95 & 61 /58 (MSP/USP) & 72 & 72 \\
\hline & 7 mins & $30 \mathrm{sec}$ & $30 \mathrm{sec}$ & $30 \mathrm{sec}$ & 7 mins \\
\hline \multirow[t]{2}{*}{ BRCA1 } & 95 & 95 & 65 /61 (MSP/USP) & 72 & 72 \\
\hline & 5 mins & $30 \mathrm{sec}$ & $30 \mathrm{sec}$ & $30 \mathrm{sec}$ & 5 mins \\
\hline
\end{tabular}

Statistical analysis: Chi-square test was used to perform statistical analysis. A p-value of $<0.05$ was considered to be statistically significant.

Ethical approval: The study was approved by the institutional scientific review board and medical ethics committee and informed consent were obtained from all patients before sample collection.

\section{Results}

Promoter hypermethylation of APC gene: Promoter hypermethylation was observed in 26 of the 78 samples analyzed (33.33\%). A high percentage of methylation was observed in stage IV (66.66\%) and grade $3(46.66 \%)$ of the disease. There was no statistically significant association of APC methylation with any of the clinicopathological parameters such as histology, stage, grade, menopausal status or invasion. The representative gel image has been depicted in fig 1 and the association of methylation frequency with clinicopathologic parameters have been summarized in table 4.

Promoter hypermethylation of BRCA1 gene: 36 of the samples analyzed reported methylation for the BRCA1 gene accounting for a methylation frequency of $46.15 \%$. The methylation frequency in Stage II and stage IV of the disease was found to be $88.88 \%$ and $66.66 \%$ respectively.
A methylation frequency of $50 \%$ was noted in patients who showed $>50 \%$ invasion in the disease. The methylation frequency statistically correlated only with the stage of the disease with a p-value of 0.037936 . The association of methylation frequency with clinicopathologic parameters and the representative gel image has been depicted in table 4 and fig 2 respectively.

Table 4: Association of Methylation frequency with clinicopathological parameters.

\begin{tabular}{|c|c|c|c|c|}
\hline \multicolumn{2}{|c|}{$\begin{array}{l}\text { Clinicopathological } \\
\text { Parameters }\end{array}$} & $|\mathbf{N}|$ & $\begin{array}{c}\text { APC } \\
\text { methylation }\end{array}$ & $\begin{array}{c}\text { BRCA1 } \\
\text { methylation }\end{array}$ \\
\hline \multicolumn{2}{|c|}{ Endometrial tumors } & 78 & & \\
\hline \multirow[t]{7}{*}{ Type of tumor } & Endometriod & 60 & $18(30 \%)$ & $28(46.66 \%)$ \\
\hline & Serous & 06 & $3(50 \%)$ & $2(33.33 \%)$ \\
\hline & Mucinous & 02 & $1(50 \%)$ & $1(50 \%)$ \\
\hline & Clear cell & 02 & $1(50 \%)$ & $1(50 \%)$ \\
\hline & $\begin{array}{l}\text { Poorly } \\
\text { differentiated }\end{array}$ & 08 & $3(37.5 \%)$ & $4(50 \%)$ \\
\hline & total & 78 & $26(33.33 \%)$ & $36(46.15)$ \\
\hline & P-value & & 0.806544 & 0.975926 \\
\hline \multirow[t]{5}{*}{ FIGO stage } & $\mathrm{I}$ & 64 & $21(32.81 \%)$ & 25 (39.06) \\
\hline & II & 9 & $2(22.22 \%)$ & $8(88.88)$ \\
\hline & III & 2 & $1(50 \%)$ & $1(50 \%)$ \\
\hline & IV & 3 & $2(66.66 \%)$ & $2(66.66 \%)$ \\
\hline & P-value & & 0.520651 & $0.037936 *$ \\
\hline \multirow{3}{*}{$\begin{array}{l}\text { Histological } \\
\text { grade }\end{array}$} & 1 & 44 & $16(36.36 \%)$ & $22(50 \%)$ \\
\hline & 2 & 19 & $3(15.78 \%)$ & $9(47.36 \%)$ \\
\hline & 3 & 15 & $7(46.66 \%)$ & $5(33.33 \%)$ \\
\hline
\end{tabular}




\begin{tabular}{|l|l|l|l|l|}
\hline & P-value & & 0.134432 & 0.531197 \\
\hline \multirow{4}{*}{ Menopausal status } & Premenopausal & 10 & $3(30 \%)$ & $3(30 \%)$ \\
\cline { 2 - 5 } & Postmenopausal & 68 & $23(33.82 \%)$ & $33(48.52 \%)$ \\
\cline { 2 - 5 } & P-value & & 0.81073 & 0.272442 \\
\hline Invasion & $<50 \%$ & 52 & $18(34.61 \%)$ & $23(44.23 \%)$ \\
\cline { 2 - 5 } & $>50 \%$ & 26 & $8(30.76 \%)$ & $13(50 \%)$ \\
\cline { 2 - 5 } & pValue & & 0.734095 & 0.629939 \\
\hline
\end{tabular}

Figure 1:

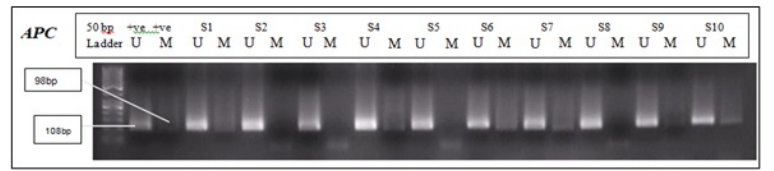

Figure 1: Representative agarose gel image depicting the methylation pattern of APC in endometrial cancer samples.

\section{Figure 2:}

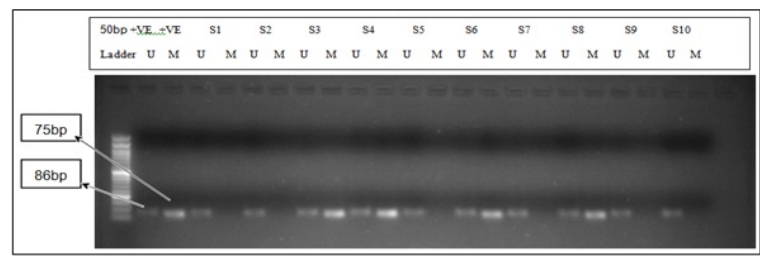

Figure 2: Representative agarose gel image depicting the methylation pattern of BRCA1 in endometrial cancer samples.

\section{Discussion}

Genetic alterations such as mutations generally lead to the gain of function in the otherwise silent oncogenes leading to the initiation of carcinogenesis. Epigenetic alterations on the other hand do not lead to changes in nucleotide sequence but involve the covalent addition of methyl or acetyl groups to bases in the DNA [37]. In the case of hypermethylation, the DNA methyltransferase adds a methyl group to the fifth position of the cytosine bases that are present in the CpG island of gene promoters. This epigenetic alteration makes the binding of transcriptional machinery inaccessible to initiate gene transcription. These hypermethylation led transcriptional silencing events have been reported for several tumor suppressor genes in various types of cancers. This epigenetic change is however a reversible process and thus has been a promising hope towards designing personalized therapies for cancers $[37,38]$.

APC protein is known to play an important role in cell cycle regulation via the wnt pathway.
The mutation is the most common cause of APC inactivation but epigenetic alterations such as promoter hypermethylation have also been attributed to cancer. APC gene promoter hypermethylation has been extensively studied and reported to be involved in the early development of colon cancer. A 24\%, 27\%, 33\%, 53 \% methylation was reported by various groups in colorectal cancer [39-42]. A methylation frequency of $71 \%$ in inflammatory breast cancer, $82.5 \%$ in gastric carcinoma and $95 \%$ in non-small cell lung carcinoma have also been reported [43-45]. A 77\% methylation was reported in early stage endometrial cancers by Ignatova $A$ et al., and a $43 \%$ methylation was reported by Zysman Met al., and $17.86 \%$ by Ghazanfari T et al., respectively [46-48]. These results are similar to the methylation frequency (33.33\%) reported for APC in the present study. BRCA1 gene hypermethylation has been studied extensively in breast and ovarian cancer. Studies in breast cancer have reported a methylation frequency ranging between $5.2 \%$ to $65.2 \%$ [49-52]. A 5\%-56\% methylation has been reported in ovarian cancer [34, 53-59]. The aberrant promoter hypermethylation of BRCA1 has not been reported in endometrial cancers as per the search results available in PubMed. The current study reports a methylation frequency of $46.15 \%$.

\section{Conclusion}

Aberrant promoter hypermethylation of APC and BRCA1 occurs in endometrial cancer and this methylation frequency has been observed in the early stages of cancer. The methylation pattern can therefore be used in the early diagnosis of endometrial cancer along with previously available methods.

\section{What this study adds to the existing knowledge}

The promoter hypermethylation event is an early epigenetic alteration in tumorigenesis. The current study reports the methylation frequency of two TSG (APC and BRCA1) in endometrial cancer. No data are reporting the methylation frequency of BRCA1 in endometrial cancer available and therefore the result presented in this research can add useful insight into the silencing of the BRCA1 gene in endometrial cancer. In addition, methylation-based markers serve as an important tool in the diagnosis and prognosis of cancers. 


\section{Author Contributions}

Nagaratna Shivanandappa: Study design, Experimental design, Experimentation, data collection, manuscript writing, statistical analysis, manuscript writing and editing.

Shalini N Swamy: experimental design, manuscript writing and editing, statistical analysis.

Sandeep Kumar S: manuscript writing and editing, statistical analysis.

Suma Sheshadri: data collection and sample screening.

Pallavi V R: data collection and sample selection.

Ramesh Gawari: Study design, experimental design manuscript writing, editing, statistical analysis.

\section{Reference}

01. Banno K, Kisu I, Yanokura M, Masuda K, Kobayashi $Y$, Ueki $A$, et al. Endometrial Cancer and Hypermethylation: Regulation of DNA and MicroRNA by Epigenetics. Biochem Res Int. 2012;2012:738274. doi: 10.1155/2012/738274 [Crossref][PubMed][Google Scholar]

02. Huo X, Sun H, Cao D, Yang J, Peng P, Yu M, Shen $K$. Identification of prognosis markers for endometrial cancer by integrated analysis of DNA methylation and RNA-Seq data. Sci Rep. 2019 Jul 9;9(1):9924. doi: 10.1038/s41598-019-46195-8 [Crossref][PubMed][Google Scholar]

03. Siegel RL, Miller KD, Jemal A. Cancer statistics, 2016. CA Cancer J Clin. 2016 Jan-Feb;66(1):7-30. doi: 10.3322/caac.21332 [Crossref][PubMed] [Google Scholar]

04. Vrba L, Futscher BW. A suite of DNA methylation markers that can detect most common human cancers. Epigenetics. 2018;13(1):61-72. doi: 10.1080/15592294.2017.1412907 [Crossref] [PubMed][Google Scholar]

05. Tao MH, Freudenheim JL. DNA methylation in endometrial cancer. Epigenetics. 2010 Aug 16;5(6):491-8. doi: 10.4161/epi.5.6.12431 [Crossref][PubMed][Google Scholar]

06. Hao X, Luo H, Krawczyk M, Wei W, Wang W, Wang $J$, et al. DNA methylation markers for diagnosis and prognosis of common cancers. Proc Natl Acad Sci U S A. 2017 Jul 11;114(28):74147419. doi: 10.1073/pnas.1703577114 [Crossref] [PubMed][Google Scholar]
07. Munemitsu S, Souza B, Müller O, Albert I, Rubinfeld $B$, Polakis P. The APC gene product associates with microtubules in vivo and promotes their assembly in vitro. Cancer Res. 1994 Jul 15;54(14):3676-81. [Crossref][PubMed][Google Scholar]

08. Barth AI, Pollack AL, Altschuler Y, Mostov KE, Nelson WJ. NH2-terminal deletion of beta-catenin results in stable colocalization of mutant betacatenin with adenomatous polyposis coli protein and altered MDCK cell adhesion. J Cell Biol. $1997 \mathrm{Feb}$ 10;136(3):693-706. doi: 10.1083/jcb.136.3.693 [Crossref][PubMed][Google Scholar]

09. Munemitsu S, Souza B, Müller O, Albert I, Rubinfeld B, Polakis P. The APC gene product associates with microtubules in vivo and promotes their assembly in vitro. Cancer Res. 1994 Jul 15;54(14):3676-81. [Crossref][PubMed][Google Scholar]

10. Neufeld KL, White RL. Nuclear and cytoplasmic localizations of the adenomatous polyposis coli protein. Proc Natl Acad Sci U S A. 1997 Apr 1;94(7):3034-9. doi: 10.1073/pnas.94.7.3034 [Crossref][PubMed][Google Scholar]

11. Henderson BR. Nuclear-cytoplasmic shuttling of APC regulates beta-catenin subcellular localization and turnover. Nat Cell Biol. 2000 Sep;2(9):653-60. doi: 10.1038/35023605 [Crossref][PubMed][Google Scholar]

12. Fearnhead NS, Britton MP, Bodmer WF. The ABC of APC. Hum Mol Genet. 2001 Apr;10(7):721-33. doi: $10.1093 / \mathrm{hmg} / 10.7 .721$ [Crossref][PubMed] [Google Scholar]

13. Goss $\mathrm{KH}$, Groden J. Biology of the adenomatous polyposis coli tumor suppressor. J Clin Oncol. 2000;18(9):1967-79. doi: 10.1200/JCO.2000.18. 9.1967 [Crossref][PubMed][Google Scholar]

14. Ishidate $T$, Matsumine $A$, Toyoshima $K$, Akiyama T. The APC-hDLG complex negatively regulates cell cycle progression from the G0/G1 to $\mathrm{S}$ phase. Oncogene. 2000 Jan 20;19(3):365-72. doi: 10.1038/sj.onc.1203309 [Crossref][PubMed] [Google Scholar]

15. Nakamura $M$, Zhou $X Z$, Lu KP. Critical role for the EB1 and APC interaction in the regulation of microtubule polymerization. Curr Biol. $2001 \mathrm{Jul}$ 10;11(13):1062-7. doi: 10.1016/s09609822(01)00297-4 [Crossref][PubMed][Google Scholar] 
16. Behrens J, von Kries JP, Kühl M, Bruhn L, Wedlich D, Grosschedl R, Birchmeier W. Functional interaction of beta-catenin with the transcription factor LEF-1. Nature. 1996 Aug 15;382(6592):63842. doi: 10.1038/382638a0 [Crossref][PubMed] [Google Scholar]

17. Morin P J, Sparks A B, Korinek V, Barker N, Clevers $H$, Vogelstein $B$, et al. Activation of $\beta$ catenin-Tcf signaling in colon cancer by mutations in $\beta$-catenin or APC. Science. 275;5307(1997)17871790. [Crossref][PubMed][Google Scholar]

18. Korinek V, Barker N, Morin PJ, van Wichen D, de Weger $\mathrm{R}$, Kinzler $\mathrm{KW}$, et al. Constitutive transcriptional activation by a beta-catenin-Tcf complex in APC-/- colon carcinoma. Science. 1997 Mar 21;275(5307):1784-7. doi: 10.1126/science.275.5307.1784 [Crossref] [PubMed][Google Scholar]

19. He TC, Sparks AB, Rago C, Hermeking $H$, Zawel $L$, da Costa LT, et al. Identification of c-MYC as a target of the APC pathway. Science. 1998 Sep 4;281(5382):1509-12. doi: 10.1126/science.281.5382.1509

[PubMed][Google Scholar]

[Crossref]

20. Shtutman $M$, Zhurinsky J, Simcha I, Albanese C, D'Amico $M$, Pestell $R$, et al. The cyclin D1 gene is a target of the beta-catenin/LEF-1 pathway. Proc Natl Acad Sci U S A. 1999 May 11;96(10):5522-7. doi: 10.1073/pnas.96.10.5522 [Crossref][PubMed] [Google Scholar]

21. Mann B, Gelos $M$, Siedow A, Hanski $M L$, Gratchev A, Ilyas $M$, et al. Target genes of betacatenin-T cell-factor/lymphoid-enhancer-factor signaling in human colorectal carcinomas. Proc Natl Acad Sci U S A. 1999 Feb 16;96(4):1603-8. doi: 10.1073/pnas.96.4.1603 [Crossref][PubMed] [Google Scholar]

22. Jaiswal AS, Narayan S. A novel function of adenomatous polyposis coli (APC) in regulating DNA repair. Cancer Lett. 2008 Nov 28;271(2):272-80. doi: $10.1016 / j$.canlet.2008.06.024 [Crossref] [PubMed][Google Scholar]

23. Miki Y, Swensen J, Shattuck-Eidens D, Futreal PA, Harshman K, Tavtigian S, et al. A strong candidate for the breast and ovarian cancer susceptibility gene BRCA1. Science. 1994 Oct 7;266(5182):66-71. doi: 10.1126/science.7545954 [Crossref][PubMed][Google Scholar]
24. Friedman LS, Ostermeyer EA, Szabo CI, Dowd P, Lynch ED, Rowell SE, King MC. Confirmation of BRCA1 by analysis of germline mutations linked to breast and ovarian cancer in ten families. Nat Genet. 1994 Dec;8(4):399-404. doi: 10.1038/ng1294-399 [Crossref][PubMed][Google Scholar]

25. Catteau A, Morris JR. BRCA1 methylation- a significant role in tumour development?. Semin Cancer Biol. 2002 Oct;12(5):359-371. doi: 10.1016/s1044-579x(02)00056-1 [Crossref] [PubMed][Google Scholar]

26. Scully R, Chen J, Ochs RL, Keegan K, Hoekstra M, Feunteun J, Livingston DM. Dynamic changes of BRCA1 subnuclear location and phosphorylation state are initiated by DNA damage. Cell. 1997 Aug $8 ; 90(3): 425-35 . \quad$ doi: 10.1016/s00928674(00)80503-6 [Crossref][PubMed][Google Scholar]

27. Hartwell LH, Weinert TA. Checkpoints: controls that ensure the order of cell cycle events. Science. 1989 Nov 3;246(4930):629-34. doi: 10.1126/science.2683079 [Crossref][PubMed] [Google Scholar]

28. Fabbro $M$, Savage $K$, Hobson $K$, Deans $A J$, Powell SN, McArthur GA, Khanna KK. BRCA1-BARD1 complexes are required for p53Ser-15 phosphorylation and a G1/S arrest following ionizing radiation-induced DNA damage. J Biol Chem. 2004 Jul 23;279(30):31251-8. doi: 10.1074/jbc.M405372200 [Crossref][PubMed] [Google Scholar]

29. Bernstein C, Bernstein H, Payne CM, Garewal H. DNA repair/pro-apoptotic dual-role proteins in five major DNA repair pathways: fail-safe protection against carcinogenesis. Mutat Res. 2002 Jun;511(2):145-78. doi: 10.1016/s13835742(02)00009-1 [Crossref][PubMed][Google Scholar]

30. Wu J, Lu LY, Yu X. The role of BRCA1 in DNA damage response. Protein Cell. 2010 Feb;1(2):11723. doi: 10.1007/s13238-010-0010-5 [Crossref] [PubMed][Google Scholar]

31. Dobrovic A, Simpfendorfer D. Methylation of the BRCA1 gene in sporadic breast cancer. Cancer Res. 1997 Aug 15;57(16):3347-50. [Crossref][PubMed] [Google Scholar] 
32. Rice JC, Ozcelik H, Maxeiner $P$, Andrulis I, Futscher BW. Methylation of the BRCA1 promoter is associated with decreased BRCA1 mRNA levels in clinical breast cancer specimens. Carcinogenesis. 2000 Sep;21(9):1761-5. doi: 10.1093/carcin/21.9.1761 [Crossref][PubMed] [Google Scholar]

33. Morizono A, Tanabe $M$, Ikemura $M$, Sasaki $T$, Ushiku T, Seto $Y$. Loss of BRCA1 expression and morphological features associated with BRCA1 promoter methylation status in triple-negative breast cancer. J Hum Genet. 2021 Aug;66(8):785793. doi: 10.1038/s10038-021-00911-3. [Crossref] [PubMed][Google Scholar]

34. S SK, Swamy SN, Premalatha CS, Pallavi VR, Gawari R. Aberrant Promoter Hypermethylation of RASSF1a and BRCA1 in Circulating Cell-Free Tumor DNA Serves as a Biomarker of Ovarian Carcinoma. Asian Pac J Cancer Prev. 2019 Oct 1;20(10):30013005. doi: 10.31557/APJCP.2019.20.10.3001 [Crossref][PubMed][Google Scholar]

35. Kalachand RD, Stordal B, Madden S, Chandler B, Cunningham J, Goode EL, et al. BRCA1 Promoter Methylation and Clinical Outcomes in Ovarian Cancer: An Individual Patient Data Meta-Analysis. J Natl Cancer Inst. 2020 Dec 14;112(12):1190-1203. doi: 10.1093/jnci/djaa070 [Crossref][PubMed] [Google Scholar]

36. Tabano S, Azzollini J, Pesenti C, Lovati S, Costanza J, Fontana L, et al. Analysis of BRCA1 and RAD51C Promoter Methylation in Italian Families at High-Risk of Breast and Ovarian Cancer. Cancers (Basel). 2020 Apr 8;12(4):910. doi: 10.3390/cancers12040910 [Crossref][PubMed] [Google Scholar]

37. Baylin SB. DNA methylation and gene silencing in cancer. Nat Clin Pract Oncol. 2005 Dec;2 Suppl 1:S4-11. doi: 10.1038/ncponc0354 [Crossref] [PubMed][Google Scholar]

38. Jones PA, Baylin SB. The fundamental role of epigenetic events in cancer. Nat Rev Genet. 2002 Jun;3(6):415-28. doi: 10.1038/nrg816 [Crossref] [PubMed][Google Scholar]

39. Kamiyama H, Noda H, Takata O, Suzuki K, Kawamura Y, Konishi F. Promoter hypermethylation of tumor-related genes in peritoneal lavage and the prognosis of patients with colorectal cancer. J Surg Oncol. 2009 Jul 1;100(1):69-74. doi: 10.1002/jso.21291 [Crossref][PubMed][Google Scholar]
40. Lee BB, Lee EJ, Jung EH, Chun HK, Chang DK, Song SY, et al. Aberrant methylation of APC, MGMT, RASSF2A, and Wif-1 genes in plasma as a biomarker for early detection of colorectal cancer. Clin Cancer Res. 2009 Oct 1;15(19):6185-91. doi: 10.1158/1078-0432.CCR-09-0111 [PubMed][Google Scholar]

[Crossref]

41. Matthaios D, Balgkouranidou I, Karayiannakis A, Bolanaki $\mathrm{H}$, Xenidis $\mathrm{N}$, Amarantidis $\mathrm{K}$, et al. Methylation status of the APC and RASSF1A promoter in cell-free circulating DNA and its prognostic role in patients with colorectal cancer. Oncol Lett. $2016 \mathrm{Jul} ; 12(1): 748-756$. doi: 10.3892/ol.2016.4649 [Crossref][PubMed][Google Scholar]

42. Chen J, Röcken C, Lofton-Day C, Schulz HU, Müller $\mathrm{O}$, Kutzner $\mathrm{N}$, et al. Molecular analysis of APC promoter methylation and protein expression in colorectal cancer metastasis. Carcinogenesis. 2005 Jan;26(1):37-43. doi: 10.1093/carcin/bgh280 [Crossref][PubMed][Google Scholar]

43. Van der Auwera I, Van Laere SJ, Van den Bosch SM, Van den Eynden GG, Trinh BX, van Dam PA, et al. Aberrant methylation of the Adenomatous Polyposis Coli (APC) gene promoter is associated with the inflammatory breast cancer phenotype. $\mathrm{Br}$ J Cancer. 2008 Nov 18;99(10):1735-42. doi: 10.1038/sj.bjc.6604705 [Crossref][PubMed][Google Scholar]

44. Tsuchiya T, Tamura G, Sato K, Endoh $Y$, Sakata $K$, Jin $Z$, et al. Distinct methylation patterns of two APC gene promoters in normal and cancerous gastric epithelia. Oncogene. 2000 Jul 27;19(32):3642-6. doi: 10.1038/sj.onc. 1203704 [Crossref][PubMed][Google Scholar]

45. Brabender J, Usadel $H$, Danenberg KD, Metzger $\mathrm{R}$, Schneider PM, Lord RV, et al. Adenomatous polyposis coli gene promoter hypermethylation in non-small cell lung cancer is associated with survival. Oncogene. 2001 Jun 14;20(27):3528-32. doi: 10.1038/sj.onc.1204455 [Crossref][PubMed] [Google Scholar]

46. Ignatov A, Bischoff J, Ignatov T, Schwarzenau C, Krebs $T$, Kuester $D$, et al. APC promoter hypermethylation is an early event in endometrial tumorigenesis. Cancer Sci. 2010 Feb;101(2):321-7. doi: 10.1111/j.1349-7006.2009.01397.x [Crossref] [PubMed][Google Scholar] 
47. Zysman M, Saka A, Millar A, Knight J, Chapman $W$, Bapat $B$. Methylation of adenomatous polyposis coli in endometrial cancer occurs more frequently in tumors with microsatellite instability phenotype. Cancer Res. 2002 Jul 1;62(13):3663-6. [Crossref] [PubMed][Google Scholar]

48. Ghazanfari T, Asaadi Tehrani G, Maziri P. The Relationship between the Methylation of Promoter Regions of Tumor Suppressor Genes PTEN and APC with Endometrial Cancer. Asian Pac J Cancer Prev. 2019 Aug 1;20(8):2259-2265. doi: 10.31557/APJCP.2019.20.8.2259 [Crossref] [PubMed][Google Scholar]

49. Zhang $L$, Long $X$. Association of BRCA1 promoter methylation with sporadic breast cancers: Evidence from 40 studies. Sci Rep. 2015 Dec 8;5:17869. doi: 10.1038/srep17869 [Crossref] [PubMed][Google Scholar]

50. Ignatov $T$, Poehlmann $A$, Ignatov $A$, Schinlauer A, Costa SD, Roessner A, et al. BRCA1 promoter methylation is a marker of better response to anthracycline-based therapy in sporadic TNBC. Breast Cancer Res Treat. 2013 Sep;141(2):205-12. doi: 10.1007/s10549-013-2693-9 [Crossref] [PubMed][Google Scholar]

51. Buyru N, Altinisik J, Ozdemir F, Demokan S, Dalay N. Methylation profiles in breast cancer. Cancer Invest. 2009 Mar;27(3):307-12. doi: 10.1080/07357900802350814 [Crossref][PubMed] [Google Scholar]

52. Hsu NC, Huang YF, Yokoyama KK, Chu PY, Chen FM, Hou MF. Methylation of BRCA1 promoter region is associated with unfavorable prognosis in women with early-stage breast cancer. PLoS One. 2013;8(2):e56256. doi: 10.1371/journal.pone.0056256 [Crossref][PubMed] [Google Scholar]

53. Kalachand RD, Stordal B, Madden S, Chandler B, Cunningham J, Goode EL, et al. BRCA1 Promoter Methylation and Clinical Outcomes in Ovarian Cancer: An Individual Patient Data Meta-Analysis. J Natl Cancer Inst. 2020 Dec 14;112(12):1190-1203. doi: 10.1093/jnci/djaa070. PMID: 32413141; PMCID: PMC7735770 [Crossref][PubMed][Google Scholar]
54. Baldwin RL, Nemeth $E$, Tran $H$, Shvartsman $H$, Cass I, Narod S, Karlan BY. BRCA1 promoter region hypermethylation in ovarian carcinoma: a population-based study. Cancer Res. 2000 Oct 1;60(19):5329-33. [Crossref][PubMed][Google Scholar]

55. Esteller M, Silva JM, Dominguez G, Bonilla $F$, Matias-Guiu $X$, Lerma $E$, et alPromoter hypermethylation and BRCA1 inactivation in sporadic breast and ovarian tumors. J Natl Cancer Inst. $2000 \mathrm{Apr}$ 5;92(7):564-9. doi: 10. 1093/jnci/92.7.564 [Crossref][PubMed][Google Scholar]

56. Dhillon VS, Aslam M, Husain SA. The contribution of genetic and epigenetic changes in granulosa cell tumors of ovarian origin. Clin Cancer Res. 2004 Aug 15;10(16):5537-45. doi: 10.1158/1078-0432.CCR-04-0228 [Crossref] [PubMed][Google Scholar]

57. Wiley $A$, Katsaros $D$, Chen $H$, Rigault de la Longrais IA, Beeghly $A$, Puopolo $M$, et al. Aberrant promoter methylation of multiple genes in malignant ovarian tumors and in ovarian tumors with low malignant potential. Cancer. 2006 Jul 15;107(2):299-308. doi: 10.1002/cncr.21992 [Crossref][PubMed][Google Scholar]

58. Mancini DN, Rodenhiser DI, Ainsworth $P J$, O'Malley FP, Singh SM, Xing $W$, et al. CpG methylation within the 5 ' regulatory region of the BRCA1 gene is tumor specific and includes a putative CREB binding site. Oncogene. 1998 Mar 5;16(9):1161-9. doi: 10.1038/sj.onc. 1201630 [Crossref][PubMed][Google Scholar]

59. An J, Wei Q, Liu Z, Lu KH, Cheng X, Mills GB, Wang LE. Messenger RNA expression and methylation of candidate tumor-suppressor genes and risk of ovarian cancer-a case-control analysis. Int J Mol Epidemiol Genet. 2010;1(1):1-10. [Crossref][PubMed][Google Scholar] 